\title{
A Research Paper on Contamination of Water Due to Fluoride, Lead and Arsenic and its Removal Techniques
}

\author{
Nidhi Jain, Huzaif Umarsharif Mujawar
}

\begin{abstract}
Due to undesirable changes in the physical, chemical and biological characteristics of air, water and soil people across the globe have been subjected to severe environmental catastrophes. With no signs of stabilization of population explosion, rapid industrialization, have polluted the essential resources beyond threshold In this changing scenario availability of quality water is an indispensable feature for preventing diseases and improving quality of life. It is of utmost importance to assimilate the details of different physico-chemical parameters viz. color, temperature, acidity, hardness, $\mathrm{pH}$, sulphar and chloride content, $\mathrm{DO}, \mathrm{BOD}, \mathrm{COD}$, alkalinity used for testing of water quality. Few metals viz. fluoride, lead and arsenic in their ionic form are of are major source of water contamination affecting the aquatic ecosystem and terrestrial life forms.

The paper addresses the effect of different adsorbents used for removal of fluoride, arsenic and lead.
\end{abstract}

Keywords: water, physic - chemical, hardness, fluoride, lead and arsenic contamination

\section{INTRODUCTION}

Water is a magical substance. It is both simple and complex in nature. A water molecule is composed of atoms of hydrogen and oxygen. $\mathrm{H}_{2} \mathrm{O}$. The makeup of these building blocks produces a molecule with almost magical properties, an essential element for sustenance of life on earth.. The excessive loss of water from human body leads to severe health complications sometimes turning fatal.

Water quality at a certain location and time based on. A water quality index (WQI) based on several quality parameters was developed by Scientist form National Sanitation Foundation (NSF) in 1970. The NSF WQI provides a standardized method for comparing the water quality of various water bodies.

As per estimates the amount of fluoride found in earth crust is around 85 million tones and nearly 12 million tones are located in India. The principal sources of fluorine are drinking water, food derived from aquatic sources, cheese and tea. Fluoride is present in all forms of water and in particular higher concentrations is found in in ground.

\section{Toxicity:}

Skeletal and dental flurosis are caused by high fluoride level in drinking water which acts has critical health hazard

\footnotetext{
Revised Manuscript Received on 14 September, 2019.

Dr. Nidhi Jain, Department of Engineering Science, Bharati vidyapeeth college of engineering Lavale, Pune - 412115,Maharashtra, India. (Email: nidhijain1704@gmail.com)

Huzaif Umarsharif Mujawar, Department of Computer Engineering, Bharati vidyapeeth college of engineering Lavale, Pune-412115,
} Maharashtra, India. (Email: huzaifmujawar1998@gmail.com) which forms the basis for its wide variety of uses. Water is

\section{Fluoride:}

of this century. It was estimated that 62 million people were found to be affected with varying degree of fluorosis in India such as dental, skeletal and non-skeletal form of fluorosis [Susheela, A. K, 2001].

Two-edged sword is called as Fluoride It is beneficial for the human body as it is made up of $96 \%$ of fluoride in the form of bones and teeth. Mineralization of bones and formation of dental enamel fluoride plays important role.

If it is ingested in large quantity above daily requirement it cause through drinking water it causes dental and skeletal fluorosis [Park, K. 2011].
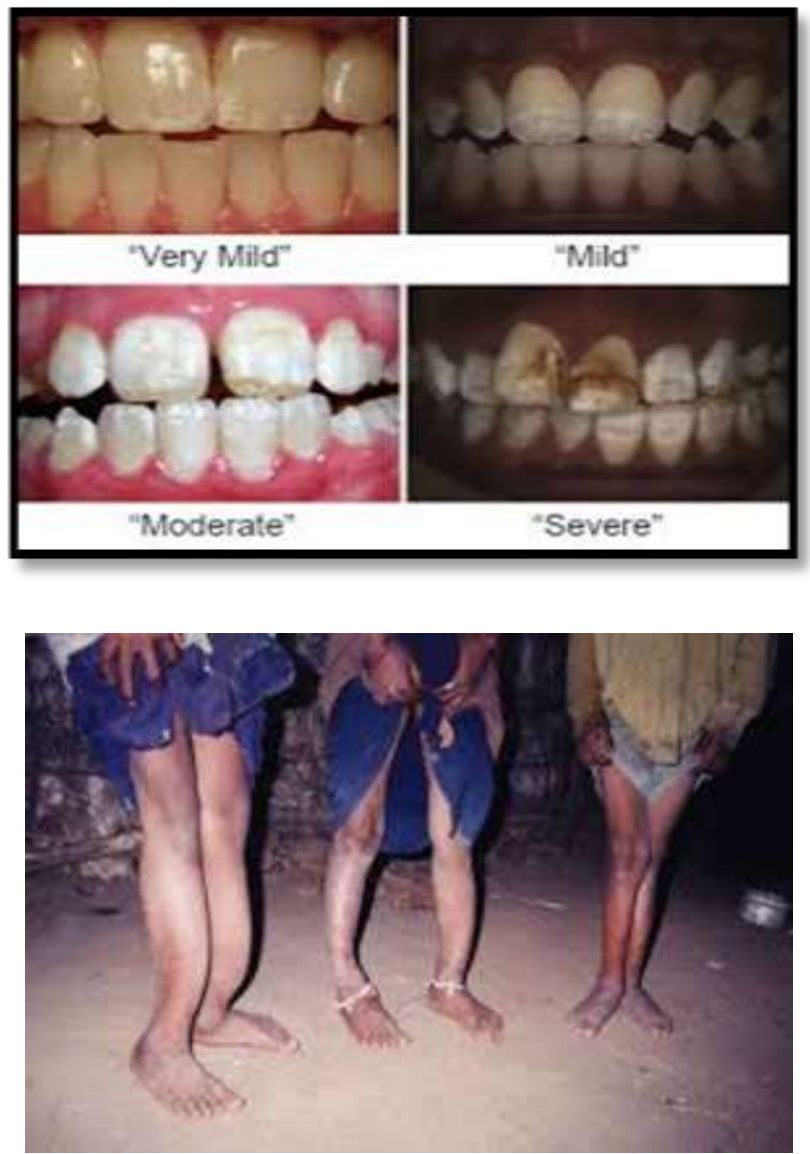

There are two types of cation by which fluoride is associated one is water soluble monovalent cations such as $\mathrm{NaF}$ and $\mathrm{KF}$. And second one is water in soluble with divalent cations such as $\mathrm{CaF}_{2}$ and $\mathrm{PbF}_{2}$

If we compare the toxicity of fluoride we find that

Fluoride is "more toxic than lead and less toxic than arsenic”. [Jain, J. K.,Gupta, Nidhi, 2013] 


\section{REMOVAL TECHNIQUES}

According to WHO, 2006 guidelines fluoride is an essential mineral (WHO, 2006) which is beneficial when taken within permissible limits and also causes as well as various disorders such as skeletal fluorosis, brittle bones, cancer, infertility in women and Alzheimer syndrome [Dobaradaran, S. 2008, Guo, X.,et al 2003, Mahvi, A, 2006] .

\section{Lead}

Atmospheric lead concentrations of $50 \mathrm{pg} / \mathrm{m} 3$ have been found in remote areas. Levels of lead in soil range between 10 and $70 \mathrm{mg} / \mathrm{kg}$ and a mean level near roadways of 138 $\mathrm{mg} / \mathrm{kg}$ have been reported. Present levels of lead in water rarely exceed a few micrograms/liter; the natural concentration of lead in surface water has been estimated to be $0.02 \mathrm{~m} \mathrm{~g} /$ liter [Gavaghan, Helen].

Lead is hazardous to mankind as well as for the environment because [Verstraeten, S.,2008].Generally lead is in elemental form, cannot be scale down into less dangerous material. Major health problems associated with neurological and physiological repercussions. Paint is the major source of lead ingestion. In US 38 million households used lead containing paints in 2002 and out of which significant lead based hazards are caused. [Tripathi, R. M., et al, 2001].,[Toscano, C., Guilarte, T.;2005.]

\section{Toxicity:}

Contaminated ground water has the major source of diseases by heavy metals ions such as lead etc. Plumbism is caused by lead toxicity. It can also be caused by inhaling contaminated air.

Large numbers health problems are caused by

Lead toxicity and its cause toxic effect on human body [Navas-Acien, A., 2007 etal.,Woodruff et al.,2008, Iqbal, S., etal.,2008] Some of the major problems caused by lead are blood disorders and Anaemia, Rapid deterioration of brain and the nervous system, Reduced fertility both in men and women, Failure of the kidney, Alzheimer disease.

In 2000, the allowable level of lead in drinking water was reduced from $0.6 \mathrm{ppm}$ to $0.05 \mathrm{ppm}$. However, no level of lead is considered to be actually safe today.

About $90 \%$ of the lead body burden is stored in the bones and teeth of adults. The corresponding value for children is $70 \%$. Higher mobility of lead in children results from continuous growth and re/desorption of bone making children more susceptible to the adverse health effects of lead. Similar bone lead mobilization also occurs during pregnancy. [Barbosa, F.,etal.,2005] and elevated blood lead concentrations have been associated with reduced hemoglobin synthesis and red blood cell quantity [Tripathi, R. M., 2001]leading, in the worst case, to anaemia.

Parkinson's disease and amyotrophic lateral sclerosis are also major caused by Lead contamination. Lead effects enzyme production with heme which in turn spoil energy metabolism,

[Khan, A 2008]. lead poisoning can be controlled by taking proper precautionary measures Environmental and domestic sources of $\mathrm{Pb}^{2}$ [Robert,et al,2008].

\section{Arsenic}

Arsenic $(\mathrm{As} 3+/ 5+)$ is ubiquitous in nature and widely distributed in soils, sediments, water and atmosphere.
Arsenic is a metalloid with atomic number 33 and atomic weight $74.9216 \mathrm{~g} / \mathrm{mol}$. In the terrestrial environment, concentration of as ranges from $1.5-3 \mathrm{mg} \mathrm{kg}-1$ and found as the 20th most plentiful element in earth's crust [Mahimairaja, S.,2005]. In seawater and human beings it is ranked the 14th and 12th element in abundance, respectively.

Arsenopyrite. is the most prevalent form of Arsenic, as arsenic is a metalloid which is ubiquitous as organic and inorganic in the ecosystem. The compounds like arsenite and arsenate that are the inorganic forms of arsenic tend to show higher rate of toxicity in humans than other natural counterparts.

The king of Poison is what Arsenic is Frequently referred to as it is discreet, accessible, unscented and leaves no taste: hence can go easily undetected in daily intake.

Inorganic source of arsenic is mainly geological where as that of organic if the marines. The first ever Arsenic poisoning dates back to July, 1983 in the region of West Bengal.[Mukherjee, A.et al.,2006].

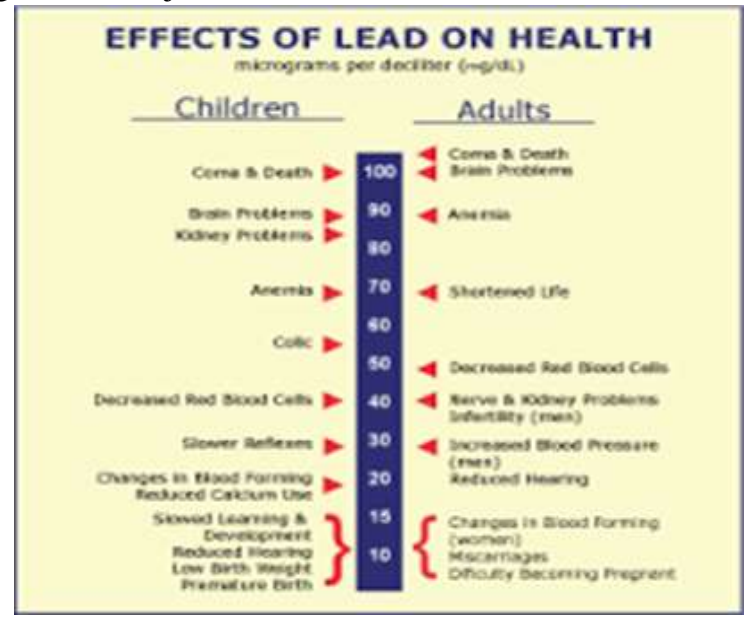

The geothermal fluids that have abundance of arsenic tend to comtaminate the surface water when in contact. [Garelick, H et al., 2008]. The contribution to arsenic flux in the environment is mainly from the dissolution of the compound Aresenopyrite or the arsenic which is released from rocks or sediments. One of the main Atmospheric depletion due to arsenic is caused by the coal fired power generation plants or by burning vegetation and volcanism.

The Percentage of arsenic in earth's crust varies a lot, in the range of about 1 to 40 part to about a million parts of soil (ppm) with an average of about 3-4 ppm. However, the areas such as mining or smelting sites or the places where arsenic induced pesticides had been applied in the fields can show a lot higher levels of arsenic.

The Ground water carries a rich level of arsenic than that of surface water, and since the consumption of ground water is more in INDIA, it causes a wide range of toxicity. Ingestion of as little as $100 \mathrm{mg}$ usually results in severe poisoning and $130 \mathrm{mg}$ has proved to be fatal. All human beings are exposed to it in one form or other. However water and food constitutes major source of exposure to population [Datta, D. V., and Kaul, M. K,1976].. The stability, solubility and toxicity of arsenic depends on

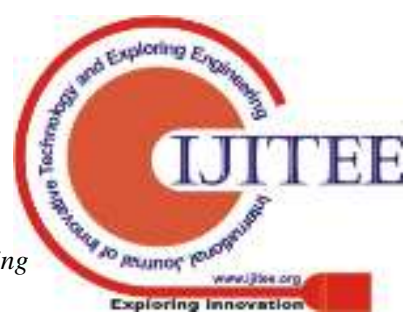


the various forms that it is found in. The Persistent and bio available inorganic forms of arsenic, that are more hazards when compared to their organic [Gupta, S., Gupta, V.; 2013].

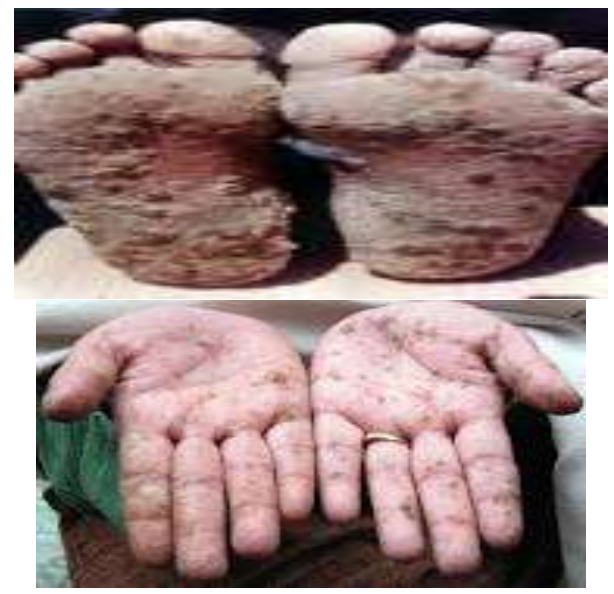

Arsenic lesions on feet and arsenic poisoning in hand

The following figures illustrate the arsenic toxicity in various part of body. The accumulation of arsenic in tissues leads to health hazards [Vahter, M., Concha, G.2001].

Exposure to inorganic arsenic causes many adverse health effects, including cardiovascular, hepatic and renal disease in addition to cancer in kidney, liver, lungs, urinary bladder and skin [Puthenveedu et al.,2012]. Scientists have made sure to do all the necessary tests to prevent the public from the hazards of toxic chemicals and constantly in search of ways to cure the effected.

\section{REVIEW OF LITERATURE}

\section{Review of fluoride levels in water.}

There has been a huge increase of fluoride in ground waters in the leading developed and developing countries that includes India around 19 states are facing acute fluorosis problem[Mehto, A., Chakrapani, G. J.,2013]. Consumption of this fluoride rich water $(>1.5 \mathrm{mg} / \mathrm{l})$ is a major source of health hazards in Humans. [Puthenveedu et al., 2012].

The presence of floride can be detected unanimously in the world, ranging from water (higher concentration in ground water), mineral deposits, rocks, also can be found in products used in our daily lives i.e. toothpaste, drugs, cosmetics, chewing gums, mouthwashes and so on. When used in small proportions it has certain benefits as well as in preventing Dental problems when used in the concentration of below $1.0 \mathrm{ppm}$, anything above that is hazardous and harmful. According to the World Health Organization (WHO) and IS: 10500 have stated to keep the levels of fluoride form 1.0 to a max of $1.5 \mathrm{ppm}$ in drinking water. [Thatte, C. D.1994, Subba, Rao, N et al 1997]. When exposed to higher levels of fluoride may lead to join pain, cancer and even partial paralysis. [Cantor, K. P.;1997] possibly raise the risk of some bone defoematiseThe main source of fluoride in this modern era are the excess use of fluoride based fertilizers or the coal that are fluoride infiltrated used in Thermal Power plants which play a major role in polluting the surrounding areas. A lot of reports related to this have been recorded, one such coming from North India. [Pathak, R. P.,2012].

A disease such as Fluorosis was first detected in India in the early 1930s in four states and by the year 1992 it was recorded to be found in as many as 177 districts across 19 states. [Waheped, S.,et al.,2009].

If we talk about the problem across the globe, as many as 200 million peoples in 25 nations are affected by health issues due to increase in the level of fluoride in drinking water. Countries like India and China are the ones who have been hit by this problem the most. As a matter of fact, in India the endemic fluorosis has affected a total of around 1 million alone and is said to have a major problem in more than half of the country, especially in the states of Rajasthan and Gujarat. [Rao, R. J., Naidu, M. G. C,1973.,Brunt, R. L. et al,2004].

There are serious problems faced in various countries because of rise in the presence of fluoride in drinking water, which is a source of major dental and skeleton related issues.. There have been reports in high concentrations of fluoride in ground water in more than 28 countries that carry both the developed as well as developing which also includes India, in which it is found in around 19 states.[Sharma, B. S.et al.,2011]. Levels of Fluoride that are above the prescribed limit $(1.5 \mathrm{mg} / \mathrm{l})$ in the consuming water turns into a very hazardous drink that lead to dental fluorosis and skeleton fluorosis.

[Punita Parikh et al., 2013] a recent study was done to check the status of fluoride in ground water of Kheralu block of Mehasana district, Gujarat. It showed that, in around 43 villages i.e about more than $55 \%$, it is seen that the level of fluoride are in a range of $1-1.5 \mathrm{ppm}$ out fo which around 16 villages had their levels checked and resulted in a level below $1 \mathrm{ppm}$ while the 27 villages showed a level that exceeds the maximum level of around $1.5 \mathrm{ppm}$. The factors which have lead to this may be due to the reason of major loss of surface water and presence of semiarid climate along with sedimentary rock basin.

The other documents which are reviewed on fluoride contamination of water are Kataria et al 2008]. It states that the content of fluoride in the surface and ground water in the city of Bhopal salve et al,2008] have also been reported to have gone past the acceptable limit which also the same in that of kadi tehsil in the region of Mehsana in the state of Gujarat.

Review of literature on fluoride contamination reveals that the Gujarat, Rajasthan and Andhra Pradesh [Unicef state of art report 1999 FR \& R'DF data bank] are the areas which have been the most affected by the fluorosis in which more than half of their districts i.e. 18 of 24 are highly prone to be hit by fluorisis, this is due to the high levels of fluoride in their waters. In north region of Gujarat, where districts like Mehsana, Patan and Banaskantha have been majorly effected, apart from other affected districts like Amreli, Ahemdabad Sabarkantha and Baroda.[Punita,et al.,2013] Banaskantha are affected by high fluoride concentrations. Mehsana, Patan, and [Kundu N. et al., 2001] have investigated that the geochemical raise of fluoride in the ground water that is in the area of Nayagarh district 


\section{REMOVAL TECHNIQUES}

of Orissa.. There study result shows that the composition of the hot spring water is very comparable to the other thermal waters of the world. Thermodynamic considerations show that more than $65 \%$ of the groundwater and hot spring water samples are oversaturated with calcite, and only four samples are oversaturated with fluorite. Fluoride concentration shows a positive relation to sodium, bicarbonate and $\mathrm{pH}$, and a negative relation to calcium and magnesium in fluoride rich groundwater and hot spring water. Principal component analysis shows that the fluoride rich groundwater was produced due to a mixing of hot spring water with the surrounding groundwater.

Datta B.K. et al. [74] have reported that the Stable isotope (180) which investigates on the processes of controlling fluoride contamination of ground water. The reports showed that about $50 \%$ of the entire area is being affected by fluoride contamination and that the level of fluoride has gone beyond the required limit. The environs of brick kilns are found to have high levels of fluoride in their ground waters.

\section{Review of removal of fluoride in water}

A lot of research has been done in the field of removal of fluorine from drinking water by many researchers across the globe. The removal of fluorine is divided in two sections mainly dealing with Membrane and various adsorption methods. Techniques such as reverse osmosis, nanofilteration, electro-dialysis have been talked about under the first half. In adsorption, i.e. a very conventional technique which uses adsorbents like alumina/aluminum based materials along with clays and soil, material that are calcium based, also carbon based material and synthetic compounds are used. There are also reviews that have been done on the removal of fluoride from aqueous solution with the help of different type of zeolites such as reversed and modified, then certain ion exchange resins that are based on the crosslinked polystyrene.. Below are such developments which are being discussed.

Even though the use of membrane has fruitfully lowered down the levels of fluoride to the required levels, the surface adsorption still plays an eminent role in the research of defluoridation due to its great accessibility and low stress on the pocket. It is due to this reason that even when there are new techniques which are gaining popularity, researchers still prefer to explore in the greater depths to improve lowcost adsorbents so as to increase their overall effectiveness. [Biswas, K.et al.,2007].

[A. V. Jamode et al., 2004] came across a way in the form of very low-cost technique involving the use of adsorbents in the form of leaf. In this study of leafs such as that of neem (Azadirachta indica), pipal (Ficus religiosa) and khair (Acacia catechu wild) trees were used. It was found that when the fluoride ion concentration level is at its peak, in the effluent the level of fluoride ion bit by bit comes down to $0 \mathrm{mg} / \mathrm{l} \mathrm{keeping} \mathrm{the} \mathrm{conditions} \mathrm{at} 29 \pm 0.5^{\circ} \mathrm{C}$ for a period of $180 \mathrm{~min}$ and the dose of adsorbent is kept at $10 \mathrm{~g} / \mathrm{l}$. there is an isotherm called Langmuir which a process adsorption which involves statistical and experimental data calculated from Isotherm equation.

[Mohammad Mehdi Mehrabani Ardekani et al , 2013] compared the following three in respect for fluoride removal from water by adsorption, they are Bagas, Modified Bagas and Chitson. The optimum or best possible set-up for these to work efficiently could be seen when the $\mathrm{pH}$ value is set at 7 , a contact time of $60 \mathrm{~min}$ with the adsorbent dose fixed at $2 \mathrm{~g} / \mathrm{L}$ The $\mathrm{pH}$ value of 7, contact time of $60 \mathrm{~min}$ and adsorbent dose of $2 \mathrm{~g} / \mathrm{L}$ were determined as optimum conditions for all three adsorbents. Chitosan and Bagasse do not show great potential for removal of fluoride, whereas the modified bagas shows an enormous rate of about $90 \%$ of removal of fluoride in the same above mentioned conditions. Compounds like Langmuir and Freundlich isotherms also show moderately good correlation for account of required results, but the Langmuir model with the correlation value of 0/99 is superior. [Valencia-Leal S. A. et al., 2012.] The Maximum adsorption which was recorded is seemed to have occurred at pH5.0 to 8.0.at first the procees was found to be endothermic in nature. Later Langmuir and Freundlich isotherm models wear used to get the estimate data of the adsorption rate. To describe the kinetics related to fluoride adsorption in which the guava seeds are used, the pseudosecond order model is used. The Langmuir model is used to best describe the isotherm's experimental data that shows us the adsorption mechanism using guava seeds in the fluoride ions is chemisorptions when done on a homogeneous material.

[Veeraputhiran V. and Alagumuthu G. et al, 2011] studied the use of Phyllanthus Emblica as adsorbent for fluoride removal from the aqueous solution. The highest recorded adsorption capacity was found at neutral $\mathrm{pH}$ with $0.75 \mathrm{~g}$ of the adsorbent dose used, the adsorption process was that of heterogeneous with percentage removal of fluoride recorded was $82.1 \%$ by Phyllanthus embilica.

[C. M. Vivek Vardhan and J. Karthikeyan ,2011]carried out different ways to remove the fluoride contamination from water by using a certain physic-chemical method for adsorption by using very cost effective materials like rice husk, use of certain chemicals like manganese sulphate and manganese chloride, Rice husk, etc.

It was seen that when rise husk is used at a constant weight of $6 \mathrm{~g} / \mathrm{L}, 83 \%$ of fluoride from a sample of $5 \mathrm{mg} / \mathrm{l}$ fluoride solution in a span of 3 hours was removed. At and approximate rate of 92,94 and $91 \%$ respectively for removal of fluoride from a test solution of $5 \mathrm{mg} / \mathrm{l}$ at a set dosage of $1000 \mathrm{mg} / \mathrm{l}$ by using Moringa oleifera seed extracts, Manganese Sulphate and Manganese Chloride. It was observed that when manganese sulphate, Manganese Chloride and MOE is used for fluoride removal, the best suited condition for the same is at a set $\mathrm{pH}$ of 6.0. [Mohan, S. V.et al.,2007].

A range of other adsorbents systems such as the activated ions like carbon, alumina and bauxite as well as the use of natural and synthetic zeolite and use of various other ion exchange resins for removal of fluoride contamination in water.

Published By:

Blue Eyes Intelligence Engineering

\& Sciences Publication 
[Nigussie W. et al., 2007] have made a report in which they recorded a successful method of fluoride removal by the use of waste or residue left behind in the manufacturing of alum in industries, it was observed that in the initial phase the adsorption of fluoride was very rapid for around $5 \mathrm{~min}$ and as we move on it showed a gradual increase up until it reaches the equilibrium condition at around the 1 hour mark. As the adsorbent dosage was increased the efficiency could be seen to climb on to the higher side.the use of heat and surface neutralization could have no effect on raising the bar of efficiency in fluoride removal. There is seen a constant rate of removal observed when $\mathrm{pH}$ is kept at around 3-8 $\mathrm{pH}$.

The adsorption data at ambient $\mathrm{pH}$ were well fitted to the Dubinin-Radushkevick (D-R) isotherm model with a capacity of $332.5 \mathrm{mg} / \mathrm{g}$ of the adsorbent. The adsorption kinetic was found to follow a pseudo-second-order rate equation with an average rate constant of $2.25 \mathrm{gm}$ in $(-1) \mathrm{mg}$ $(-1)$.

[Sarkar M. et al., 2006] have found a way of removal of fluoride, in that of Laterite. A variety of tests have been done on the different functionality ratios of that of Laterite for as to use as a removal agent. The areas such as thermodynamic parameters like free energy change, entropy of the process and enthalpy as well as the basic sorption isotherm were also investigated.

The extent of solute removal is determined by initial solute concentration, operational conditions, laterite dose, and solution $\mathrm{pH}$. For a fixed set of experimental conditions, a model equation is developed from which the percent removal corresponding to each load of fluoride is determined. The elution of the retained fluoride was studied and the effectiveness of column operation was determined by the retention-elution cycles.

Lots of researcher had work on removal of fluoride by adsorption and adsorbent are as follows Pali Shahjee et al ,2013, Naba Kumar et al ,2012, Bhagyashree M et al,2012, Das Kumar et al 2011.

\section{Review of lead contamination in water}

Lead is well known non - biodegradable toxic metal in the environment and now it has become a global health issue [Gracia, R. C., et al ,2007, Mc Carthy et al,2006]. One of the earliest recorded diseases is that of the Lead poisoning. It has a major threat on the public health and safety measure, especially in that of the upcoming developing countries. If exposed to lead poisoning it was recorded certain hazards such as that of on the hematopoietic, renal, and reproductive and central nervous system mainly caused due to the increased levels of oxidative stress. [Flora,et al.,2012].

The reports that are collected have shown that there is a great interlink between chronic lead exposure to children and impaired cognitive skills, reduced IQ [Miranda, M.L, 2007], it is also seen that the chronic lead exposures towards adults have lead to the damage towards the problems mentioned above. [Shih, R. A., 2007].

Leaded crystal, cigarette smoke, lead solder used in canned foods produced outside the United States, children's toys, vinyl lunchboxes, contaminated candy imported from Mexico, and children's jewellery produced outside the United States have all been shown to contain significant amounts of lead.
In the year 1996 in the area of North Carolina it was surveyed that, around 75 percent of children were exposed to lead poisoning cases in a short period of six-month which includes the major contributor to this cause i.e. the lead dust from vinyl mini-blinds.[Norman, E. H. et al,1997].

The symptoms after being exposed to lead, were growth deficiency, lowered intelligence levels, loss in hearing and memory loss. After prolonged exposure to higher levels it may lead to a severe brain damage and even death [Cleveland,L. M.,2008]. This also leads to a reduced lifespan for the circulating erythrocytes by the increase in fragility of cell membranes. The total aftermath of this leads to anaemia.[Cornelis,R., 2005, Guidotti, T. L., 2008].

Literature survey showed that lead contamination in water, food and air is increased day by day. Recently we read in newspaper Maggie 2- minutes [Times of India 3June 2015] noodles contains dangerously high levels of lead which causes an estimated 143,000 deaths a year worldwide. As per our various review of literature, the presence of lead in water in various cities is presented in table 2.1

\begin{tabular}{l|l|l|l|}
\hline Table No. 2.1 & LEAD CONTENT IN WATER \\
\hline ALARMING & HIGH & MEDIUM & LOW \\
\hline Kolkata & Delhi & Chennai & Bangalore \\
\hline Kochi & Coimbatore & Ludhiana & Ahmadabad \\
\hline Mumbai & Madurai & Surat & Hyderabad \\
\hline Pune & Bhubaneswar & Ghaziabad & Indore \\
\hline Nagpur & & Jamshedpur & Bhopal \\
\hline Nasik & & & Chandigarh \\
\hline Guwahati & & & Lucknow \\
\hline & & & Mangalore \\
\hline & & & Mysore
\end{tabular}

In which about $41 \%$ sample of potable water were unfit for drinking LEAD action news,2010. The elevated levels of lead in blood of children $200 \mu \mathrm{g} / \mathrm{L}$ and in dogs it is 250 $\mu \mathrm{g} / \mathrm{L}$ of Indian mega cities were reported. From 1970's to this decay though surface water and ground water. K. S. Patel has reported the lead environmental pollution in [Patel K. S., et al 2019.] Lead to be the toxic metal Kumar, K. S.,2008 with very little or no nutrient values, is abundant almost everywhere in the nature.

[Dooyema, C. A., and their co-workers 2012] have studied on the Outbreak of fatal childhood lead poisoning related to artisanal gold mining in northwestern Nigeria. Their goal was to determine the cause of the childhood lead poisoning outbreak, investigate risk factors for child mortality, and identify children $<5$ years of age in need of emergency chelation therapy for lead poisoning.

Lead exposure to human being had been found worldwide. Documentation of lead poisoning from environmental sources and occupational setting in literature has been well mentioned some of them are Rajappa B.et al.,2010, K. Ravichandran et al., 2011

On the basis of review of literature on lead in ground water, we have concluded that the industrialization, anthropogenic activity and geochemical processes are main sources of lead in drinking water. 


\section{A RESEARCH PAPER ON CONTAMINATION OF WATER DUE TO FLUORIDE, LEAD AND ARSENIC AND ITS \\ REMOVAL TECHNIQUES}

Review of lead removal in water.

The Water used in the industrial sector leads to a lot of potential dangers to the environment by the introduction of soil and water resource damaging contents in the form of heavy metals. These heavy metals hold a major role in what is known as the pollutants for the degradation of our natural resources. [Brinza L.,et al.,2009]

Thus there is greater need to treat and have a safe way to discharge this contaminated water. The important polluting contents are like that of $\mathrm{Cd}, \mathrm{Zn}, \mathrm{Pb}$ and $\mathrm{Ni}$.

Nowadays, with a drastic increase in population, it is a high time to control the emission of such toxic materials in the environment.

[Mousavi H. Z., Hosseynifar A., Jahed V., 2010], [Maximous, N, George F., \& Wan K.;,2010.] The lead exposure tends to have a serious effect on our health in the form of anaemia, nervous disorders, kidney disease and even death in major exposures.

[Kafia M. and Surchi Shareef ,2011] have found ways to use the agricultural waste as a substitute Low Cost Adsorbent for the removal of $\mathrm{Pb}$. With the help of these five low-cost natural adsorbents which give us an efficiency rate of $85,90,100,86$ and 98 percentage respectively, these are chalf, rice husk, sesame, sun flower and residue of tea.

[Brooks Robert M., 2010 ] have observed the process in which to lower down the lead quantity from its aqueous solution by the use of AAM-PRB i.e. alkali ash material permeable reactive barrier which is a newly developed novel material with the help of fly ash alkali to remove lead (pb). The AAM-PRB were created with high permeability capabilities. The permeability ration must be high so for a barrier material around $10-2 \mathrm{~cm} / \mathrm{sec}$ to $10-1 \mathrm{~cm} / \mathrm{sec}$. The AAM-PRB are formed from three sources with permeability in the range of $10-1 \mathrm{~cm} / \mathrm{sec}$ and later crushed into pellets.

[Pandhare et al., 2013] have investigated the use of neem leaves with powdered activated carbon as adsorbents. They used methyl red \& $\mathrm{K}_{2} \mathrm{Cr}_{2} \mathrm{O}_{7}$ solution and to offer this biosorbent as local replacement for existing commercial adsorbent materials.

[Gupta S. S. and Bhattacharya K. G., 2005] Used the waste from the fertilizers to creat the activated carbon to remove, $\mathrm{Pb}$ (II) $\mathrm{Hg}$ (II), $\mathrm{Cr}(\mathrm{VI})$, and $\mathrm{Cu}$ (II). The time required for the formation of initial primary adsorption was between 1 to $2 \mathrm{hrs}$. The present saturation at break point is 79.2, 75.0, 66.6 and 64.3\% for $\mathrm{Pb}^{2+}, \mathrm{Hg}^{2+}, \mathrm{Cr}^{6+}$, and $\mathrm{Cu}^{2+}$ respectively.

[Pandhare Ghanshyam and their co-workers.2013]

Investigated and reported the removal of lead from a sample solution by the use of neem leave powder.

They prepared Neem Leaves Powder as an adsorbent using chemical activation process and the surface area measured. The adsorbent material adopted was found to be an efficient media for removal of Lead (II) ion with different parameter like Adsorbent dosages, Concentration and contact time etc. They were found that the metal uptake capacity (amount of removal) of lead (II) ion decreased but the adsorption capacity (percentage of removal) increased with the decrease in the concentration of Lead (II) in the initial sample solution. Correlation coefficient and isotherm constant was also calculated from isotherm studies with different parameter.

\section{Nagpal Uma et al.,2010}

Have reported and calculated the Equilibrium sorption for $\mathrm{Pb}^{2+}$ on three different samples of biomasses. These three are formed by the help of dried leaves of the following, Terminalia Catappa, Dalbergialatifolia and Ficus benghalensis . it was found that the total amount of $\mathrm{Pb}$ ions adsorbed increased as the concentration of the initial metal ion was increased. It was observed that equilibrium sorption capacity for $800 \mathrm{mg} \mathrm{1-1} \mathrm{for} \mathrm{metal} \mathrm{solution} \mathrm{was} \mathrm{77.55,} 59.35$ and $19.35 \mathrm{mg}$ g-1 respectivelyfor the three leaves mentioned above.

Lovell Agwaramgbo et al.,2013 Investigated the use of Solid Biomaterials like Charcol, Coffee, Tea, Fishbone and Caffeine for the removal of lead from its contaminated aqueous solutions.

The results observed were as follows from a sample solution of $1300 \mathrm{ppm}$ of lead solution, Charcoal (100\%) > Tea $(97 \%)>$ Coffee Ground $(88 \%)>$ Instant Coffee $(83.5 \%)$ $>$ Coffee Bean $(82 \%)>$ Fishbone $(76 \%)>$ Caffeine $(1.3 \%)$. It was observed from these results that not all the biomaterials taken in investigation can absorb lead.

\section{Review of arsenic contamination in water}

One of the major sources of pollution concern comes from the suspensions of the bedrock/minerals and other anthropogenic activities e.g., the contaminated water coming in from mines, preservatives of wood, discharge from uncontrolled mining and metallurgical industries also the use of excessive agricultural chemicals are a major contributor to pollution. [Lacasa, E.et al,2011; Wang, S. L. et al,2009].

It leads to many health hazards such as carcinogenic effects on organs, cardiovascular and neurological effects, also effects are seen on the immune systems due to the continuous exposure to contaminated water. Major organizations around the globe like the European Union (EU), The United States (US), and The WHO have reported that a maximum value of $10 \mu \mathrm{g}$ is what is acceptable level of contamination in water as in potable water [Chetia, M. et al,2011].

As in today's world the entire population across the globe depends on sources of ground water for their daily cooking and drinking purpose. An estimate of around 105 countries in which about $>200$ million people have come in contact with the Geogenic arsenic contamination of ground water

In the region of Ganga-Meghna-Brahmaputra, >100 million people have been in risk and threatened by the arsenic contaminated groundwater. In most of the arsenic hit Asian countries the level of contamination has gone past the max level of 10ppb to as high as 50ppb.

In India the arsenic contamination is a major issue and can be said to be among the top countries who have been effected by this contamination the most.

The Arsenic contaminated groundwater is being used for agricultural purpose which in turns pollutes the food we in take as a consumer. 
In the reports that have been studied uptill now it can be firmly said that in India Logically the contamination levels in water should not be more than $5 \mathrm{ppb}$. It is also observed that the risk of being effected by cancer by the continuous consumption of highly arsenic contaminated water at $50 \mathrm{ppb}$ and $1 \mathrm{~L} /$ day is 1.3/100.[Smith, A. H.,2002].

One of the Asian countries that is severely effected by Arsenic contamination is Bangladesh. More than half of its ground water contains or is naturally contaminated by arsenic, where the contaminations leave have gone past 10 $\mu \mathrm{g} / \mathrm{L}$ [Caussy, D., Priest N. D.,2008]

In the last few decades around 35-37 million people living in the country of Bangladesh have been exposed to the toxic levels from that of the contaminated water[Argos, M.et al.,2010], from the total of its populltion count of 164 Million. [PRB.,2010].

Van Halem, S. A. Bakker et al.,2009

According to their investigations it is reported that the arsenic contamination in water supply is a problem that is taken a global scale and hit even develoved countries like that of USA and China. In the European countries the countries manily hit are Serbia, Hungary and Italy where the arsenic related problems are mainly confined to at a great scale as of now in their groundwater.

[Chaurasia et al., 2012]

On their investigation on the Finger Print of Arsenic Contaminated Water in India, It was reported that the people have been hit by diseases such as that of ulcer, skin cancer pigmentation in skin various other skin hazards due to the exposure of continuous arsenic contaminated water.

A lot more measures have been started to take place or are being proposed to help analyses the arsenic situation in India, which will in turn help in establishing preventive measures and how should we the control the arsenic contamination in water

The review has resulted in finding out that the concentration of this contamination is increasing on a day to day basis which has indirect or direct effects on the lives of people living there.

Even more studies and analysis on the problem related to arsenic contamination can be found in literature [Roy, Madhumita et al.,2014,] Sharma et al.,2013].

Singh Amrit Pal and their co-workers, 2004 have investigated the mechanisms pertaining to arsenic toxicity.

In their investications it was found that excessive exposure of such contaminated water has taken a huge toll on the health of people by opening up to the way to major diseases such as cardiovascular abnormalities, diabetes mellitus, neurotoxicity, and nephrotoxicity.

They founded that the chronic arsenic exposure is a cause of immense health distress as it accounts for the increased risk of various disorders such as cardiovascular abnormalities, diabetes mellitus, neurotoxicity, and nephrotoxicity. In addition, the exposure to arsenic has been suggested to affect the liver function and to induce hepatotoxicity. The present review addresses diverse mechanisms involved in the pathogenesis of arsenic-induced toxicity and end-organ damage.

Several other studies on contamination of arsenic are as follows: Mazumder Debendra Nath Guha ${ }^{2010}$, Basu Atreyee 2015 etc.

\section{Review of removal of arsenic in water}

There are numbers of arsenic removal methods, which include coagulation followed by precipitation, membrane separation, anion exchange; etc. Arsenic pollution has emerged as a serious public health concern in Pakistan also. The use of low-cost adsorbent obtained from a environmentally friendly materials, has been investigated as a replacement for the current expensive methods of removing arsenic from solution. There are various other low-cost adsorbents which are more superior like that of carbons that is derived from agricultural waste, bio-sorbents, goethite and other commercial adsorbents including resins, gels, silica tested.

Many other systems have been taken into account for the removal of Arsenic like ion exchange, activated alumina, reverse osmosis, modified coagulation membrane filtration and enhanced lime softening.[Berg.M.,2006]

[Eid I., et al.,2014]

Have investigated ways for the arsenic removal with the help of certain plant-based biomaterials that can easily be found in the arsenic prone areas in the country of Bangladesh. They are the powdered roots of water Hyacinth (WH) which is best for removal of arsenic type (III) and type (V), other include that of banana-pseudo stem (BN), jute and sugar cane bagasse (SC).

Razzouki B. and their co-workers.,1993 Have founds ways to remove the arsenic type (III) and (V) with help of iron hydride.

have investigated on remove As (III) and As (V) using iron hydroxide. The study was performed with the effect of $\mathrm{pH}$ and its contact time (T) on the basis of Co precipitationsorption of Arsenic (III) and Iron (III) Hydroxides. The result shows that the co-precipitation of arsenic (III) with $\mathrm{Fe}$ $(\mathrm{OH})_{3}$ was more dependent on the concentration of iron and $\mathrm{H}+$ ions. Complexation in a monodentate area was more important than the bidentate throughout the $\mathrm{pH}$ range studied, but the bidentate complex has important role near $\mathrm{pH} 8$.

[Ashraf Ali M. et al.] have been developed three $\mathrm{As}^{3+/ 5+}$ removal technologies, these were: (i) removal system based on alum and iron coagulation; (ii) sorptive filtration using iron coated sand filter, and (iii) sorptive filtration using gravel bed containing iron sludge. Also two technologies, Based on laboratory performance, ferric chloride coagulation, and sorptive filtration through iron-coated sand, were selected for the development of household arsenic removal units.

[Mohapatra D. et al., 2008] have determined that As (V) removal from an aqueous medium by calcined refectory grade bauxite (CRB) as a function of solution $\mathrm{pH}$, time, As (V) concentration and temp.

The residual value of the arsenic (V) was observed to have lowered from $2 \mathrm{mg} / \mathrm{L}$ to about $0.01 \mathrm{mg} / \mathrm{L}$ in the range of $\mathrm{pH}$ kept around $4.0-7.0$ by the use of $5 \mathrm{gm} / \mathrm{L}$ of CRB in a time span of 3 hours. Contact time 


\section{A RESEARCH PAPER ON CONTAMINATION OF WATER DUE TO FLUORIDE, LEAD AND ARSENIC AND ITS \\ REMOVAL TECHNIQUES}

\section{CONCLUSION}

Water is becoming a important factor for development and the quality of life in many countries. In arid areas it has even become a survival factor. There is need to have proper flow. Upon the various research done It can be concluded that the major source of pollution may have come from a natural path or/even manmade. The researchers have successfully found ways to lower down or remove the contamination of the compounds discussed i.e. F, Pd and $\mathrm{As}^{3+15+}$ from the waters, which in turn help in solving a variety of problems caused not only in India but worldwide as well.

\section{REFERENCES}

1. Argos, M., Kalra T., Rathouz P. J., Chen Y., Pierce B., Parvez F., Islam T., Ahmed A., Rakibuz-Zaman M., Hasan R., Sarwar G., Slavkovich V., Geen, A. V., Graziano, J., Ahsan H.; Arsenic exposure from drinking water, and all-cause and chronic-disease mortalities inBangladesh (HEALS):A prospective cohort study.; Lancet 2010, Vol. 376, pp 252-258. Delwar Hossain, M., Hussainuzzaman, M. M., Badruzzaman, M., O. I., Mohammad, N. Akter.; Development of Low-cost Technologies for Removal of Arsenic from Groundwater.; pp 99-120.

3. Basu, Atreyee, Sen Parijat, Jha Ayan.; Environmental arsenic toxicity in West Bengal, India: A brief policy review.;Indian J Public Health.; 2015, 59, pp 295-298.

4. Berg, M., Luzi S., Trang P. T. K., Viet P. H.; Giger, W., Stuben D.; Arsenic removal from groundwater by household sand filters: Comparative field study, model calculations, and health benefits., Environ. Sci. Technol.; 2006, 40, 5567-5573.

5. Bhagyashree, M., Mamilwar, A., G., Bhole, A. M., Sudame.; International Journal of Engineering Research

6. Brooks Robert M.; Bahadory Mozhgan, Tovia Fernando, Rostami Hossein.; Removal of Lead from Contaminated Water.; International Journal of Soil, Sediment and Water; 2010, Vol. 3: Iss. 2, pp 14.

7. Brunt, R. L., Vasak, J., Griffioen.; A report: Fluoride in groundwater: Probability of occurrence of excessive concentration on global scale.; International groundwater resources assessment centre.; 2004.

8. Biswas, K., Saha, S. K., Ghosh, U. C.; Adsorption of fluoride from aqueous solution by a synthetic iron(III)aluminum(III) mixed oxide.; Ind. Eng. Chem. Res.; 2007, Vol. 46, pp 5346-5356.

9. Cantor, K. P.; Drinking water and cancer.; Cancer Causes Control.; 1997,8(3):292-308.

10. Caussy, D., Priest N. D.; Introduction to arsenic contamination and health risk assessment with special reference to Bangladesh.; Rev. Environ. Contamin. Toxicol.; 2008, Vol. 197, pp 1-15.

11. Chaurasia, Neha, Mishra, Amarnath, Pandey, S. K.; Finger Print of Arsenic Contaminated Water in India-A Review.; J. Forensic Res.; 2012,Vol. 3, pp 10.

12. Chetia, M., Goswamee R. L., Banerjee S., Chatterjee S., Singh L., Srivastava R. B., Sarma H.P.; Arsenic removal from water using calcined $\mathrm{Mg}-\mathrm{Al}$ layered double hydroxide.; Clean Techn. Environ. Policy.; 2011, doi: 10.1007/s10098-011-0365-1.

13. Cleveland, L. M., Minter M. L., Cobb K. A., Scott A. A., German V. F.; Lead hazards for pregnant women and collection and treatment of waste and need to regulate the

2. Ashraf, Ali, M., Badruzzaman, A. B. M., Jalil, M. A., and Applications (IJERA).; 2012, Vol. 2(4), pp 334-338. children: Part 1: immigrants and the poor shoulder most

of the burden of lead exposure in this country. Part 1 of a two part article details how exposure happens, whom it affects, and the harm it can do.; Am J Nurs.; 2008, Vol. 108, pp 40-49.

14. Cornelis, R. Handbook of elemental speciation II: species in the environment, food, medicine \& occupational health.; Wiley.; 2005.

15. C. M., Vivek, Vardhan, J., Karthikeyan.; Removal of fluoride from water using low-cost materials.; Fifteenth International Water Technology Conference.; IWTC-15; 2011, Alexandria, Egypt.

16. Das, Kumar Malay, Attar, J., Salim.; Comparative Study of Batch Adsorption of Fluoride Using Commercial and Natural Adsorbent.; Research Journal of Chemical Sciences.; 2011, Vol. 1(7), pp 68-75.

17. Dadwhal, M., Sahimi M., Tsotsis T. T.; Adsorption isotherms of arsenic on conditioned layered double hydroxides in the presence of various competing ions.; Ind. Eng. Chem. Res.; 2011, 50, 2220-2226.

18. Datta, D. V., Kaul, M. K.; Arsenic content in drinking water in villages of Northern India.; J. Assoc. Phy. Ind.; 1976, Vol. 24, pp 599-604..

19. Dooyema, C. A., Neri A., Lo Y. C., Durant J., Dargan P. I., Swarthout T., Biya O., Gidado S. O., Haladu S., SaniGwarzo N., Nguku P. M., Akpan H., Idris S., Bashir A. M. ,Brown M. J.; Outbreak of fatal childhood lead poisoning related to artisanal gold mining in northwestern Nigeria.; Environ Health Perspect.; 2012,Vol. 120(4), pp 601-7.

20. Eid I., Brima Parvez, I. Haris.; Arsenic Removal from Drinking Water using Different Biomaterials and Evaluation of a Phytotechnology Based Filter.;Int. Res. J. Environment Sci.; 2014, Vol. 3(7), pp 39-44.

21. Flora, Gagan, Gupta, Deepesh, Tiwari, Archana; Toxicity of lead: A review with recent updates.; Interdiscip Toxicol.; 2012, Vol. 5(2), pp 47-58.

22. Garelick, H., Jones, H., Dybowska, A., Valsami-Jones, E.; Arsenic pollution sources. Rev. Environ.Contam. Toxicol.; 2008, Vol. 197, pp 1760.

23. Gracia, R. C., Snodgrass, W. R.; Lead toxicity and chelation therapy.; Am.J. Health-System Pharm.; 2007, Vol. 64, pp 45-53.

24. Guidotti, T. L., Mc Namara J., Moses M. S.; The interpretation of trace element analysis in body fluids.; Indian J Med Res.; 2008, Vol.128, pp 524-532.

25. Gupta S. S.; Bhattacharya K. G.; Interaction of metal ions with Clays: I, A case study with $\mathrm{Pb}(\mathrm{II})$.; Appl. Clay Sci.; 2005, Vol. 30(3-4), pp 199-208.

26. Gupta, S., Gupta, V.; Speciation and toxicity of arsenic: a human carcinogen. Res. J. Recent Sci.; 2013, Vol. 2, pp $45-53$.

27. Jamode, A., Sapkal, V.; Defluoridation of water using inexpensive adsorbents.; J. Indian Ins. Sci.; 2004, Vol. 84(5), pp 163-171.

28. Kataria, K. C., Bux, S., Namdeo, M.; study of fluoride content in ground water and surface water of Bhopal city.; I.J.E.P.; 2008, Vol. 29(5), pp 461-464.

29. Kafia, M., Shareef Surchi.; Agricultural Wastes as Low Cost Adsorbents for $\mathrm{Pb}$ Removal: Kinetics, Equilibrium and Thermodynamics.; International Journal of Chemistry.; 2011, Vol. 3(3), pp 103.

30. Kumar, K. S., Sajwan, K. S., Richardson, J. P., Kannan, K.; Contamination profile of heavy metals.; U.S.A.; Mar. Pollut. Bull.; 2008, Vol. 56, pp 136-149.

31. Kundu, N., Panigrahi, M., Tripathy, S., Munshi, S., Powell, M., Hart, B.; Geochemical appraisal of fluoride contamination of groundwater in the Nayagarh District of Orissa, India.; Environmental 
Geology.; 2001, Vol. 41, pp 451-460.

32. Lacasa, E., Canizares, P., Saez, C., Fernandez, F. J., Rodrigo, M. A.; Removal of arsenic by iron and aluminium electrochemically assisted coagulation.; Separ. Purific. Technol.; 2011, Vol. 79, pp 15-19..

33. Lovell Agwaramgbo, Nichole Lathan, Shelby Edwards, ShaKayla Nunez.; Assessing Lead Removal from Contaminated Water Using Solid Biomaterials: Charcoal, Coffee, Tea, Fishbone, and Caffeine.; Journal of Environmental Protection; 2013, Vol. 4, pp741-745.

34. Maximous, N, George F., \& Wan K.; Removal of Heavy Metals from Wastewater by Adsorption and Membrane Processes: a Comparative Study.; World Academy of Science, Engineering and Technology.; 2010, pp 64.

35. Mazumder, Debendra Nath Guha, Ghosh Aloke , Mazumder, Kunal Kanti, Ghosh,Nilima, Saha, Chandan , Mazumder, Rathindra Nath Guha.; Arsenic contamination of ground water and its health impact on population of district of Nadia, West Bengal, India.; 2010, Vol. 35( 2), pp 331-338.

36. Mc Carthy, Hafner, H. R., Montzka, S. A.; Background concentration of 18 air toxics for North America.; J.Air Waste Manage. Assoc.; 2006, Vol. 56, pp 3-11.

37. Miranda, M. L., Dohyeong, K., Galeano, M. A., Paul, C. J., Hull, A. P., Morgan, S. P.; The Relationship between Early Child Hood Blood Lead Levels and Performance on End-of-Grade Tests.; Environmental Health Perspectives.; 2007, Vol. 115, pp 1242-1247.

38. Mohammad, Mehdi, Mehrabani, Ardekani, Roshanak, Rezaei, Kalantary, Sahand, Jorfi, Mohammad, Nurisepehr.; Comparison the Efficiency of Bagas, Modified Bagas and Chitosan for Fluoride Removal from Water by Adsorption.; Journal of Environmental Treatment Techniques.; 2013, Vol. 1(1), pp 1-7.

39. Mehto, A., Chakrapani, G. J.; Spatio-temporal variation in the hydrochemistry of Tawa River, Central India: Effect of natural and anthropogenic factors.; Environmental Monitoring and Assessment.; 2013, Vol. 185(12), pp 789-9802.

40. Mohan, S. V., Ramanaiah, S. V., Rajkumar, B., Sarma, P. N.; Removal of fluoride from aqueous phase by biosorption onto algal biosorbent Spirogyra Sp.-102: sorption mechanism elucidation.; J. Hazard. Mater.; 2007, Vol. 141, pp 465-474.

41. Mohapatra D., Mishra D.; Park K.; A laboratory scale study of arsenic(V) removal from aqueous medium using calcined bauxite ore.; J. Environ. Sci. (China).; 2008, Vol. 20(6), pp 683-9.

42. Mousavi H. Z., Hosseynifar A., Jahed V., Dehghani S. A. M.; Removal of Lead from aqueous Solution using waste Tire Rubber Ash as an Adsorbent.; Brazilian Journal of Chemical Engineering.; 2010, Vol. 27(01), pp. 79-87.

43. Naba, Kr. Mondal, Ria, Bhaumik, Arnab, Banerjee, Jayanta, Kr. Datta, Tanmoy, Baur.; A comparative study on the batch performance of fluoride adsorption by activated silica gel and activated rice husk ash.; International Journal of Environmental Sciences.; 2012,Vol. 2(3), ISSN 0976 - 4402.

44. Nagpal, Uma, M. K., Rezaei Hassan.; Equilibrium sorption studies for $\mathrm{Cu} 2+$ and $\mathrm{Pb} 2+$ metal ions on three different biomasses.; Current World Environment.; 2010, Vol. 5(2), pp 243-251.

45. Nigussie, W., Zewge, F., Chandravanshi, B. S.; Removal of excess fluoride from water using waste residue from alum manufacturing process.;J Hazard Mater.; 2007, Vol.147(3), pp 954-63.

46. Norman, E. H., Hertz-Picciotto, I., Salmen, D. A., Ward, T. H.; Childhood lead poisoning and vinyl miniblind exposure.; Arch Pediatr Adolesc Med.; 1997, Vol. 151, pp 1033-1037.

47. Pali, Shahjee, B. J. Godboley, A. M. Sudame.; Removal of fluoride from aqueous solution by using low cost adsorbent.; International Journal of Innovative Research in Science, Engineering and Technology.; 2013, Vol. 2, pp 7.

48. Pandhare Ghanshyam, Trivedi Nikhilesh, Kanse Nitin, Dawande S.,D.; Synthesis of low cost adsorbent from azadirachta indica (neem) leaf powder.; International Journal of Advanced Engineering Research and Studies.; 2013,Vol. II(II), pp 29-31.

49. Park, K.; Park's Text Book of Preventive and Social Medicine. Ed 21.; Ba-narasisdas Bhanot Publishers, 1167. Premnagar, Jabalpur, India.; 2011, pp 577.

50. Pathak, R. P., Sharma, Pankaj, Vyas, Sameer, Mahure, N. V., Kumar, Rajeev, Murari Ratnam.; Detection of Fluoride Contamination in the Surface and Sub-Surface Water near Thermal Power Station.; International Journal of Engineering and Science.; 2012, Vol. 1, PP 44-47.

51. Punita, Parikh, Rahul, Parikh.; Current status of fluoride contamination in ground water of Kheralu block of Mehasana district, Gujarat.; International Journal of Environmental Sciences.; 2013, Vol. 3, pp 2199-2207.

52. Puthenveedu, Sadasivan, Pillai, Harikumar, Chonattu, Jaseela, Tharayil, Megha.; Defluoridation of water using biosorbents.; Natural Science.; 2012,Vol. 4(4), pp 245251.

53. Rajappa, B., Manjappa S., Puttaiah E.T.; Monitoring of Heavy metal concentration in ground water of Hakinaka Taluk, India.; Cont. Engin.Sci.; 2010, Vol. 3(4), pp 183 190.

54. Rao, R. J., Naidu, M. G. C.; Geochemistry of high fluoride natural waters if Jaggaiahpalem, fluorosis endemic village near Visakhapatnam district, Andhra Pradesh.; Inst. Symposium on Recent researches and applications of Geochemistry, Patna, India.; 1973, pp 6

55. Ravichandran K., Jayaprakash M.; Seasonal variation on physico chemical parameters and trace metal in ground water of an industrial area of North Chennai, India.; Ind. J.Sci. and Tech.; 2011, Vol. 4(6), pp 646-649.

56. Razzouki, B., S. EL Hajjaji, K. Azzaoui, A. Errich, A. Lamhamdi, M. Berrabah, L. L. Elansari.; Physicochemical study of arsenic removal using iron hydroxide.; J. Mater. Environ. Sci.; 2015, Vol.- 6 (5), pp 1444-1450.

57. Roy, Madhumita, Mukherjee, Apurba, Mukherjee, Sutapa, Biswas, Jaydip.; Arsenic: an alarming global concern.; Int.J.Curr.Microbiol.App.Sci.; 2014, Vol. 3(10), pp 34-47.

58. Salve, P. R., Maurya, A., Kumbhare, P. S., Ramteke, D S., Wate, S. R.; Assessment of groundwater quality with respect to fluoride.; Bulletin of environmental contamination and toxicology.; 2008, Vol. 81(3), pp 289293.

59. Sharma, B. S., Agrawal, Jyoti, Gupta, Anil, K.; Emerging Challenge: Fluoride Contamination in Groundwater in Agra District, Uttar Pradesh.; ASIAN J. EXP. BIOL. SCI.; 2011, Vol. 2(1), pp 131-134.

60. Sharma, S., Dixit, S., Jain, P., Shah, K. W., Vishwakarma, R.; Statistical evaluation of hydrobiological parameters of Narmada river at Hoshangabad city, India.; Env. Moni. and Asses.; 2008, Vol. 143 (1-3), pp 195- 202.

61. Shih, R. A. H. Hu, M. G. Weisskopf, B. S. Schwartz.; Cumulative Lead Dose and Cognitive Function in Adults. A Review of Studies that Measured both Blood Lead and Bone Lead; Environmental Health Perspectives.; 2007, Vol. 115, pp 483-492. 
62. Singh, Thakur Lokendra, Semil, Pradeep.; Removal Of Arsenic In Aqueous Solution By Low Cost Adsorbent: A Short Review.; International Journal of ChemTech Research.; 2013, Vol. 5(3), pp 1299-1308.

63. Smith, A. H., Lopipero P. A., Bates M. N., Steinmaus C. M.; Public health. Arsenic epidemiology and drinking water standards.; Science .; 2002 , Vol. 296, pp 2145-6.

64. Subba, Rao, N., Prakasa, Rao, J., Niranjan Babu, P., Chandra Rao P., Krishna, Rao G.; Hydrogeochemical zoning in crystalline terrain and its significance to water quality.; Jour.Geol. Soc. India.; 1997, Vol. 49(6), pp 715719.

65. Susheela, A. K.; "Fluorosis: Indian scienario" A treatise on fluorosis. Fluoro-sis.; Research and Rural Development Foundation; New Delhi, India.; 2001.

66. Sarkar, M., Banerjee, A., Pramanick, P. P., Sarkar, A. R.; Use of laterite for the removal of fluoride from contaminated drinking water.; J Colloid Interface Sci.; 2006, Vol. 302(2), pp 432-41.

67. Thatte, C. D.; Matching of water supply with growing demands.; J. IWWA.; 1994, 26(2): pp 67-71.

68. Valencia-Leal, S. A., R., Cortés-Martínez, R., AlfaroCuevas-Villanueva.; Evaluation of Guava Seeds (Psidium Guajava) As a Low-Cost Biosorbent for the Removal of Fluoride from Aqueous Solutions.; International Journal of Engineering Research and Development.; 2012, Vol. 5(4), pp 69-76.

69. Veeraputhiran, V., Alagumuthu, G.; Treatment of High Fluoride Drinking Water Using Bioadsorbent.; Research Journal of Chemical Sciences.; 2011, Vol. 1(4), pp 4954.

70. Waheped, S., Deshmukh, S. J., Attar, M. D., Waghmare.; "Investiga-tion on Sorption of Fluoride in Water Using Rice Husk as an AdsorbentNa-ture Environment and Pollution Technology"; An International Quarterly Scien-tific Journal.; 2009, Vol. 8(2), pp 217-223.

71. Wang, S. L., Liu C. H., Wang M. K., Chuang Y. H., Chiang P. N.; Arsenate adsorption by $\mathrm{Mg} / \mathrm{Al}-\mathrm{NO} 3$ layered double hydroxides with varying the $\mathrm{Mg} / \mathrm{Al}$ ratio.; Appl. Clay Sci.; 2009, 43, 79-85.

72. Brinza L., Nygård C. A., Dring M. J., Gavrilescu M., \& Benning L. G.; Cadmium tolerance and adsorption by the marine brown alga Fucus vesiculosus from the Irish Sea and the Bothnian Sea.; Bioresource Technology.; 2009, 100, pp 1727-1733. 